\title{
EFFECT OF DIETARY METHIONINE LEVEL ON ANSER- INE AND CARNOSINE CONTENTS IN THE GASTROCNEMIUS MUSCLE OF RAT
}

\author{
Nanaya TAMAKI, ${ }^{1}$ Mitsuko Harada, ${ }^{1}$ and Takao $\mathrm{HAMA}^{2}$ \\ ${ }^{1}$ Laboratory of Nutritional Chemistry, Faculty of Nutrition and \\ ${ }^{2}$ Laboratory of Physiological Chemistry, Faculty of Pharmacy, \\ Kobe-Gakuin University, Tarumi-ku, Kobe 673, Japan
}

(Received August 29, 1977)

\begin{abstract}
Summary Anserine and carnosine in the muscle of growing rats were measured to explore the effect of dietary methionine. Carnosine was reduced in the gastrocnemius muscle of rats fed on a methionine-free diet. After refeeding on methionine for one week, carnosine in the muscle approached to the normal level. In contrast, anserine increased in the muscle of rats fed on a methionine-free diet. Anserine also increased in the gastrocnemius muscle of rats fed on a methionine-excess diet, whereas carnosine did not vary. $\mathrm{N}^{\pi}$-Methylhistidine was detected in the muscle of rats fed on a methionine-excess diet. Moreover, $\mathrm{N}^{\pi}$-methylhistidine and $\mathrm{N}^{\tau}$ methylhistidine in the urine increased in the rats fed on both methionineexcess and methionine-free diets. Carnosine in the gastrocnemius muscle was not affected by a ethionine diet nor by a orotic acid diet which induced fatty liver. However, anserine increased in the muscle of rats fed on a ethionine diet.
\end{abstract}

Anserine ( $\beta$-alanyl- $\mathrm{N}^{\pi}$-methylhistidine) and carnosine ( $\beta$-alanylhistidine) are found in the skeletal muscle of many species of animals $(1,2)$. In spite of extensive studies, their physiological roles and metabolic fates have not yet been clarified, although carnosine has been recently proposed to act as a neurotransmitter $(3,4)$. Anserine and carnosine in the muscle of rats increase with aging $(5,6)$. Anserine is decreased by thyroidectomy (7), and carnosine is markedly decreased by feeding either a protein-free diet $(7,8)$ or vitamin $\mathrm{B}_{1}-\mathrm{B}_{2}-$ or $\mathrm{B}_{6}$-free $\operatorname{diet}(9)$ and also by treatment with ischiatic denervation (10). These dipeptides have been proposed to be synthesized from their constituent amino acids, namely $\beta$-alanine and $\mathrm{N}^{\pi}$ methylhistidine or histidine $(11,12)$. Anserine increases in the muscle of rats administered with $\beta$-alanine for 15 days (13). On the other hand, muscular carnosine in rats fed on a histidine-free diet remarkably decreases $(6,8,14,15)$.

${ }^{1}$ 玉木七八，原田光子， ${ }^{2}$ 浜 堯夫 
The methyl residue of $\mathrm{N}^{\pi}$-methylhistidine is shown to be derived from adenosylmethionine in in vitro systems (16). However, the metabolic fate of $\mathrm{N}^{\pi}$ methylhistidine is obscure. The present studies deal with effects of methionine deficiency and methionine supplement on anserine and carnosine contents in the gastrocnemius muscle of rats in order to exploit the coordination between the methionine content in the diet and the peptides contents. The effect of methionine on $\mathrm{N}^{\pi}$-methylhistidine and $\mathrm{N}^{\tau}$-methylhistidine contents in the muscle and urine of rats will also be described.

\section{MATERIALS AND METHODS}

Chemicals. All chemicals of analytical grade were purchased from Nakarai Chemicals Ltd. unless otherwise stated. Standard L-anserine nitrate, L-carnosine, L$\mathrm{N}^{\pi}$-methylhistidine and $\mathrm{L}-\mathrm{N}^{\tau}$-methylhistidine were obtained from Sigma. The reagents for amino acid analysis were purchased from E. Merck.

Animals. Male weanling Wistar rats, weighing 50 to $60 \mathrm{~g}$, were housed in individual screen bottom cages in a room maintained at $23 \pm 1{ }^{\circ} \mathrm{C}$ with $50 \%$ humidity, with light regulation ( $12 \mathrm{hr}$ light a day). The animals were given commercial food pellets (CLEA Japan, Inc.) and water ad libitum for a period of 4 to 5 days to allow them to adapt to the new environment. Rats showing progressive weight gain were selected and separated from the groups. On the last day, a 24-hr urine was collected and analyzed unless otherwise stated. Four to six animals were used in each experimental subgroup.

Methionine-free, methionine-excess, ethionine and orotic acid diets. The compositions of basal diets are presented in Table 1. In the methionine-free diet (Table 1, II), methionine and cystine were removed and glycine was added. The methionineexcess diet included 5\% methionine (Table 1, IV). In some experiments $4 \%$ of ethionine (Table 1, VI) or 1\% of orotic acid (Table 1, VII) was added to induce fatty liver.

Analysis of $\beta$-alanine, histidine, anserine, carnosine, $N^{\pi}$-methylhistidine and $N^{\tau}$ methylhistidine. The gastrocnemius muscle was homogenized with $80 \%$ ethanol, and amino acids and peptides were extracted as previously described (17). The alcohol extract was condensed in vacuo, and the residue was dissolved in citrate buffer at $\mathrm{pH} 2.2$ for amino acid analysis. Urine samples were prepared by desalting with ion exchange resin. Amino acids and peptides were determined with an amino acid autoanalyzer (Hitachi KLA-3B type) (17).

Estimation of DNA, RNA and protein. DNA, RNA and protein were estimated as previously described $(10,17)$.

Estimation of activities of glutamate oxaloacetate transaminase (GOT) and glutamate pyruvate transaminase (GPT). The blood of rats fed on an ethionine or orotic acid diet was collected, and the serum was separated as soon as possible after sacrifice. GOT (L-aspartate : 2-oxoglutarate aminotransferase : 2. 6. 1. 1) and GPT (L- 
Table 1. Composition of basal diets.

\begin{tabular}{|c|c|c|c|c|c|c|c|}
\hline \multirow{2}{*}{ Ingredients } & \multicolumn{2}{|c|}{$\begin{array}{l}\text { Methionine-free } \\
(\%)\end{array}$} & \multicolumn{2}{|c|}{$\begin{array}{c}\text { Methionine-excess } \\
(\%)\end{array}$} & \multicolumn{3}{|c|}{$\begin{array}{l}\text { Ethionine or orotic acid } \\
\qquad(\%)\end{array}$} \\
\hline & I & II & III & IV & $\mathrm{V}$ & VI & VII \\
\hline Amino acid mixture ${ }^{a}$ & 16.81 & 16.81 & - & - & - & - & - \\
\hline Casein & - & - & 5 & 5 & 20 & 20 & 20 \\
\hline Methionine & 2.80 & - & - & 5 & - & - & - \\
\hline Cystine & 0.39 & - & - & - & - & - & - \\
\hline Glycine & - & 3.19 & - & - & - & - & - \\
\hline Ethionine & - & - & - & - & - & 4 & - \\
\hline Orotic acid & - & - & - & - & - & - & 1 \\
\hline Sucrose & 22 & 22 & 22 & 22 & 22 & 22 & 22 \\
\hline Cornstarch & 44 & 44 & 59 & 54 & 44 & 40 & 43 \\
\hline Oil mixture ${ }^{b}$ & 8 & 8 & 8 & 8 & 8 & 8 & 8 \\
\hline Salt mixture ${ }^{c}$ & 4 & 4 & 4 & 4 & 4 & 4 & 4 \\
\hline Vitamin mixture $^{\mathrm{d}}$ & 0.85 & 0.85 & 0.85 & 0.85 & 0.85 & 0.85 & 0.85 \\
\hline Choline- $\mathrm{HCl}$ & 0.15 & 0.15 & 0.15 & 0.15 & 0.15 & 0.15 & 0.15 \\
\hline Cellulose & 1 & 1 & 1 & 1 & 1 & 1 & 1 \\
\hline
\end{tabular}

a Amino acid mixture in grams; Gly 2.0, Ala 3.2, Val 7.2, Leu 9.2, lle 6.1, Pro 10.6, Phe 5.0, Tyr 6.3, Trp 1.2, Ser 6.3, Thr 4.9, Arg 5.0, Lys 10.2, Asp 7.1, Glu 22.4, His 0.76. ${ }^{\text {b }}$ Soy bean oil : cod liver oil=2: 1 . ${ }^{c}$ McCollum's salt mixture. ${ }^{\mathrm{d}}$ Purchased from Tanabe amino acid research foundation.

alanine : 2-oxoglutarate aminotransferase : 2.6.1.2) were assayed by a modification of the method of ReITMAN and Frankel (18).

\section{RESULTS}

Body weight and food intake of rats fed on methionine-free, methionine-excess, ethionine and orotic acid diets

The body weight of control animals increased lineally under the experimental conditions, while that of the methionine-deficient animals decreased (Fig. 1 a). When the methionine was given after two weeks, the growth rate began to increase immediately. Food intake of the methionine-deficient group, $2.34 \pm 0.30 \mathrm{~g} / \mathrm{day} / \mathrm{rat}$, was about one-fifth of that of the control group, $10.10 \pm 0.95 \mathrm{~g} / \mathrm{day} / \mathrm{rat}$.

The effect of feeding methionine-excess in a low-protein diet to weanling rats is presented in Fig. 1(b). The body weight of $5 \%$ casein diet-fed animals remained unchanged for one week of a feeding period. However, the body weight of methionine-excess diet-fed rats was obviously decreased, and was $15 \mathrm{~g}$ less than that of the $5 \%$ casein diet-fed animals after one week. The food intake was also less in methionine-excess diet-fed animals, $3.15 \pm 0.68 \mathrm{~g} / \mathrm{day} / \mathrm{rat}$, than that in the control $5 \%$ casein-fed animals, $6.28 \pm 0.40 \mathrm{~g} / \mathrm{day} / \mathrm{rat}$.

The supplement of $4 \%$ L-ethionine to $20 \%$ casein-basal diet for one week (Table $1, \mathrm{~V}$ ) decreased the gain of body weight from $31.8 \pm 3.2 \mathrm{~g}$ to $-18.8 \pm 2.3 \mathrm{~g}$ per week. 

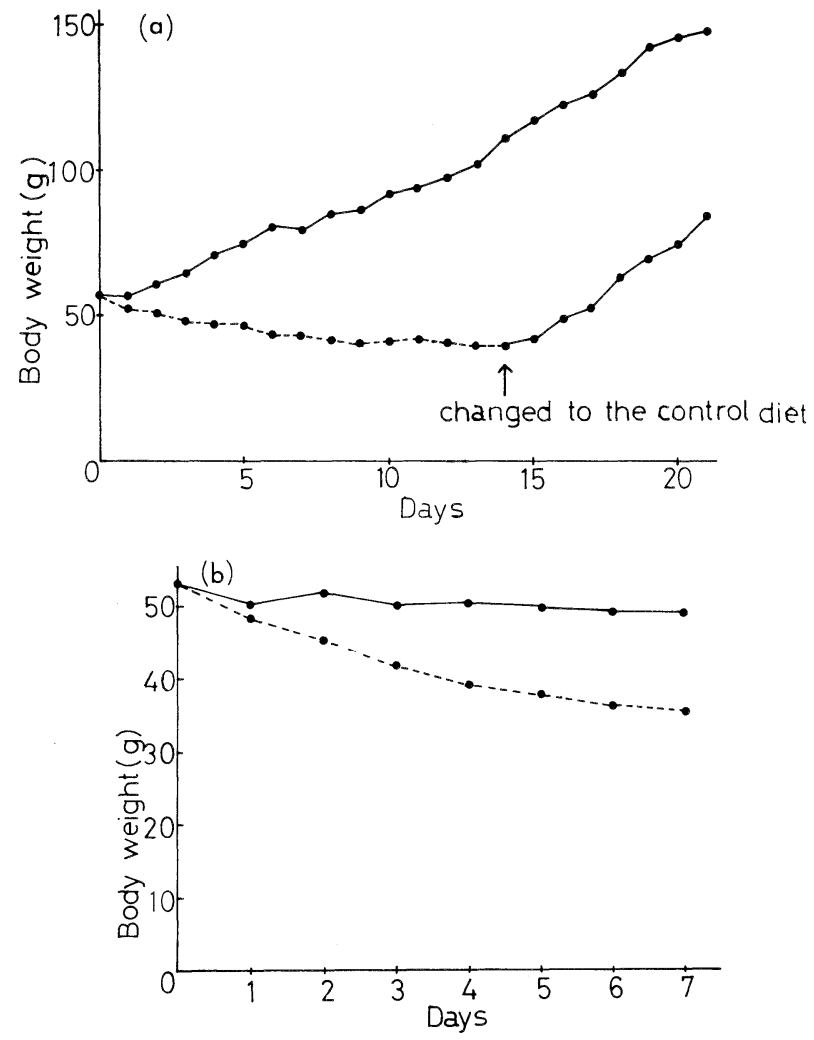

Fig. 1. Typical growth curves of experimental animals. (a) methionine-deficient rats. diet; --- methionine-free diet. (b) methionine supplemented rats. $-\bullet, 5 \%$ casein diet; - $-5 \%$ casein $+5 \%$ methionine.

The gain, $126 \pm 7 \mathrm{~g}$ per four weeks, in weight of rats fed on a diet containing orotic acid was decreased by about $70 \%$, comparing that of control rats, $170 \pm 11 \mathrm{~g}$ per four weeks, fed on a normal diet (Table 1, V).

Effects of methionine-free and methionine-excess diets on protein, DNA and RNA contents of rat gastrocnemius muscle

Protein per $g$ of wet tissue of the methionine-deficient rat gastrocnemius muscle was lower than that of the control rats (Table 2). DNA was more than that of the control rats, and RNA remarkably decreased. However, two weeks after the methionine-free diet was switched to a control diet, RNA was significantly increased. In the control rats, RNA and DNA were 0.98 and $1.15 \mathrm{mg}$ per wet tissue (g), respectively. On the other hand, in the gastrocnemius muscle of rats fed for one week on a methionine-excess diet, DNA was increased to $1.42 \mathrm{mg}$ per wet tissue $(\mathrm{g})$, whereas RNA was decreased to $0.67 \mathrm{mg}$ per wet tissue (g). 
Table 2. Effect of a methionine-free diet on protein, DNA and RNA contents in the rat gastrocnemius muscle.

\begin{tabular}{lcccc}
\hline \multicolumn{1}{c}{ Diet } & Weeks & $\begin{array}{c}\text { Protein } \\
\mathrm{g} / \text { wet tissue } \\
(\mathrm{g})\end{array}$ & $\begin{array}{c}\text { DNA } \\
\mathrm{mg} / \text { wet tissue } \\
(\mathrm{g})\end{array}$ & $\begin{array}{c}\text { RNA } \\
\mathrm{mg} / \text { wet tissue } \\
(\mathrm{g})\end{array}$ \\
\hline & 0 & $0.211 \pm 0.049$ & $0.803 \pm 0.081$ & $0.668 \pm 0.112$ \\
Control & 1 & $0.207 \pm 0.027$ & $0.760 \pm 0.074$ & $0.766 \pm 0.102$ \\
& 2 & $0.188 \pm 0.041$ & $0.792 \pm 0.062$ & $0.702 \pm 0.081$ \\
& 3 & $0.196 \pm 0.013$ & $0.688 \pm 0.073$ & $0.666 \pm 0.035$ \\
Methionine-free & 1 & $0.216 \pm 0.025$ & $1.083 \pm 0.165$ & $0.389 \pm 0.027^{* *}$ \\
& 2 & $0.204 \pm 0.021$ & $1.240 \pm 0.064^{* *}$ & $0.214 \pm 0.022^{* *}$ \\
$+\begin{array}{l}\text { Methionine and } \\
\text { cystine }\end{array}$ & 3 & $0.226 \pm 0.084$ & $1.237 \pm 0.191^{*}$ & $0.969 \pm 0.081^{*}$ \\
\end{tabular}

a Methionine-free diet was changed to control diet after two weeks. Each value is the mean \pm standard error in four to six separate experiments. ${ }^{*} p<0.05, * * p<0.01$ compared to control.

\section{Effect of methionine-free and-excess diets on anserine and carnosine contents of rat gastrocnemius muscle}

Both anserine and carnosine in the gastrocnemius muscle were increased with age as previously described $(5,6)$. However, when methionine was omitted from the diet, carnosine decreased to a half of that of the control rats after a two-week feeding period (Table 3). One week after switching to a control diet, carnosine increased but did not restore to the control level. On the contrary, anserine in the methioninedeficient diet increased significantly after a two-week feeding period. Histidine in the methionine-deficient rats also increased, but $\beta$-alanine remained unchanged.

Table 3. Effect of a methionine-free diet on $\beta$-alanine, histidine, anserine and carnosine contents in the rat gastrocnemius muscle.

\begin{tabular}{|c|c|c|c|c|c|}
\hline Diet & Weeks & $\begin{array}{c}\beta \text {-Alanine } \\
\mu \text { mole/wet tissue } \\
\text { (g) }\end{array}$ & $\begin{array}{c}\text { Histidine } \\
\mu \text { mole/wet tissue } \\
\text { (g) }\end{array}$ & $\begin{array}{c}\text { Anserine } \\
\mu \text { mole/wet tissue } \\
\text { (g) }\end{array}$ & $\begin{array}{c}\text { Carnosine } \\
\mu \text { mole/wet tissue } \\
\text { (g) }\end{array}$ \\
\hline & 0 & $0.142 \pm 0.019$ & $0.095 \pm 0.010$ & $0.624 \pm 0.069$ & $1.734 \pm 0.211$ \\
\hline \multirow[t]{3}{*}{ Control } & 1 & $0.125 \pm 0.041$ & $0.122 \pm 0.020$ & $0.777 \pm 0.034$ & $1.944 \pm 0.193$ \\
\hline & 2 & $0.168 \pm 0.033$ & $0.082 \pm 0.015$ & $0.935 \pm 0.010$ & $2.163 \pm 0.190$ \\
\hline & 3 & $0.153 \pm 0.024$ & $0.081 \pm 0.020$ & $1.146 \pm 0.064$ & $2.609 \pm 0.214$ \\
\hline \multirow[t]{2}{*}{ Methionine-free } & 1 & $0.143 \pm 0.043$ & $0.199 \pm 0.029 *$ & $0.832 \pm 0.089$ & $1.508 \pm 0.144$ \\
\hline & 2 & $0.156 \pm 0.027$ & $0.159 \pm 0.009^{* *}$ & $1.277 \pm 0.061^{*}$ & $1.295 \pm 0.136^{*}$ \\
\hline $\begin{array}{l}\text { + Methionine and } \\
\text { cystine }^{\mathrm{a}}\end{array}$ & 3 & $0.140 \pm 0.019$ & $0.145 \pm 0.019^{*}$ & $1.065 \pm 0.080$ & $1.512 \pm 0.103^{*}$ \\
\hline
\end{tabular}

a Methionine-free diet was changed to control diet after two weeks. Each value is the mean \pm standard error in four to six separate experiments. ${ }^{*} p<0.05,{ }^{* *} p<0.01$ compared to control. 


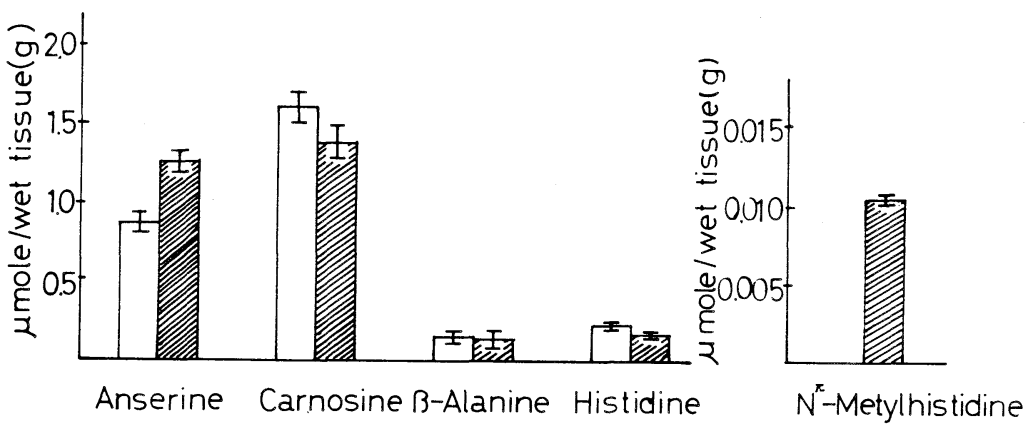

Fig. 2. Effect of a methionine-excess diet on anserine, carnosine, $\beta$-alanine, histidine and $\mathrm{N}^{\pi}$ methylhistidine. $\square, 5 \%$ casein diet; $5 \%$ casein $+5 \%$ methionine diet.

Anserine, carnosine, $\beta$-alanine, histidine and $\mathrm{N}^{\pi}$-methylhistidine in the muscle of normal and methionine-excess diet groups are given in Fig. 2. Anserine was significantly increased by feeding of a methionine-excess diet. It should be noted that $\mathrm{N}^{\pi}$-methylhistidine is detected in the muscle of rats fed on a methionine-excess diet.

\section{Excretion of methylhistidine}

$\mathrm{N}^{\pi}$-Methylhistidine and $\mathrm{N}^{\tau}$-methylhistidine in the urine of rats fed on a methionine-excess or methionine-free diet are shown in Table 4. These compounds were increased by feeding either methionine-free or -excess diet. The increase of urinary $\mathrm{N}^{\tau}$-methylhistidine was especially remarkable, when rats were maintained on a methionine-excess diet. Urinary excretion of $\beta$-alanine, anserine and carnosine was not detected in rats fed on a methionine-free or -excess diet nor in normal rats.

Table 4. Effect of a methionine-free diet on $\mathrm{N}^{\pi}$-methylhistidine and $\mathrm{N}^{\tau}$-methylhistidine in the rat urine.

\begin{tabular}{ccc}
\hline Diet & $\begin{array}{c}\mathrm{N}^{\pi} \text {-Methylhistidine } \\
\mu \text { mole/day/rat }\end{array}$ & $\begin{array}{c}\mathrm{N}^{\tau} \text {-Methylhistidine } \\
\mu \text { mole/day/rat }\end{array}$ \\
\hline $\begin{array}{c}\text { Methionine-free } \\
\text { Control (Table 1, I) }\end{array}$ & $0.243 \pm 0.030$ & $0.551 \pm 0.025$ \\
Methionine-free & $0.442 \pm 0.039^{*}$ & $0.904 \pm 0.057^{*}$ \\
Methionine-excess & & \\
$\quad$ Control (Table 1, III) & & $0.553 \pm 0.036$ \\
Methionine-excess & $0.240 \pm 0.042$ & $1.637 \pm 0.152^{* *}$ \\
\hline
\end{tabular}

a A 24-hr urine of rats fed on a methionine-free diet was collected at two weeks of the experimental period. ${ }^{\mathrm{b}}$ a $24-\mathrm{hr}$ urine of rats fed on a methionine-excess diet was collected at one week of the experimental period. * $p<0.05,{ }^{*} p<0.01$ compared to control. 
Effect of orotic acid and ethionine diets on anserine and carnosine contents of the rat gastrocnemius muscle

It is well known that ethionine is an antagonist of methionine and that ethionine or orotic acid induces a fatty liver. Therefore, effects of ethionine and orotic acid on anserine and carnosine contents in the gastrocnemius muscle were investigated. The average activities of GOT and GPT in the serum of rats fed on orotic acid for four weeks were increased to 1.82 -fold and 3.71-fold, respectively, compared with those normal rats. The average activities of GOT and GPT in the serum of rats fed on ethionine for one week increased to 2.09-fold and 3.87-fold, respectively. This suggests that a fatty liver was induced by an ethionine or orotic acid diet.

$\beta$-Alanine and histidine in the gastrocnemius muscle of rats fed on an orotic acid or ethionine diet were same level of control rats. However, anserine in the muscle of rats fed on an ethionine diet increased significantly, whereas carnosine of this rat remained unchanged (Table 5). Since the effect of a orotic acid diet on anserine and carnosine contents was not observed, the effect of an ethionine diet on these dipeptide contents did not appear as a result of a hepatitis, but seemed to result from a toxicity for rats as shown in a methionine-excess diet $(19,20)$. The differentiation of anserine and carnosine contents in control rats between experiments 1 and 2 in Table 5 was considered to be derived from the discrepancy of aging as shown in previous papers $(5,6)$

Table 5. Effect of orotic acid and ethionine diets on anserine and carnosine contents of the rat gastrocnemius muscle.

\begin{tabular}{cccc}
\hline Diet & Weeks & $\begin{array}{c}\text { Anserine } \\
\mu \text { mole } / \text { wet tissue } \\
(\mathrm{g})\end{array}$ & $\begin{array}{c}\text { Carnosine } \\
\mu \text { mole } / \text { wet tissue } \\
(\mathrm{g})\end{array}$ \\
\hline $\begin{array}{c}\text { Experiment 1 } \\
\text { Control }\end{array}$ & 4 & $2.345 \pm 0.338$ & \\
Orotic acid & 4 & $2.862 \pm 0.323$ & $5.703 \pm 0.788$ \\
Experiment 2 & & $0.623 \pm 0.102$ & $6.260 \pm 0.660$ \\
Control & 1 & $0.991 \pm 0.090^{*}$ & $1.778 \pm 0.203$ \\
Ethionine & 1 & & $1.743 \pm 0.181$ \\
\hline
\end{tabular}

* $p<0.05$ compared to control.

\section{DISCUSSION}

It has been reported that anserine biosynthesis has two possible routes, methylation of carnosine (21) and formation of peptide-linkage from $\beta$-alanine and $\mathrm{N}^{\pi}$-methylhistidine $(11,17,21-23)$; in both cases methylation step is indispensable.

The following results support our view that anserine is not biosynthesized by 
methylation of carnosine, but conjugated $\beta$-alanine and $\mathrm{N}^{\pi}$-methylhistidine in the gastrocnemius muscle of rats.

1) Anserine was increased by feeding of a methionine-excess diet, but carnosine, $\beta$-alanine and histidine were not affected.

2) $\mathrm{N}^{\pi}$-Methylhistidine, which is a component of anserine, began appearing in muscle of rats by feeding of a methionine-excess diet.

Carnosine was significantly decreased and anserine was increased, by feeding of a methionine-free diet. The result suggests that anserine is converted from carnosine, but anserine was also increased by feeding of a ethionine diet (Table 5). Therefore, the assumption is questionable.

DATTA and HARris (24) reported that the excretion of $\mathrm{N}^{\pi}$-methylhistidine was correlated with a meat diet. However, urinary $\mathrm{N}^{\pi}$-methylhistidine increased in the urine of rats fed on a methionine-excess diet (Table 4) and a histidine-excess diet (6). Furthermore, $\mathrm{N}^{\pi}$-methylhistidine was detected in the muscle of rats fed on a methionine-excess diet (Fig. 2). These results shown that $\mathrm{N}^{\pi}$-methylhistidine may be converted from histidine and methionine. Histidine methyltransferase is under investigation.

The authors are indebted to the Misses K. Kimura, S. Morioka, H. Yabu, T. Ushiro and M. Toyama for their technical assistance.

\section{REFERENCES}

1) Tallan, H. H., Moore, S., and Stein, W. H. (1954): Studies on the free amino acids and related compounds in the tissues of the cat. J. Biol. Chem., 211, 927-939.

2) Tamaki, N., Iizumi, H., Masumitsu, N., Kubota, A., and Hama, T. (1976): Species specificity on the contents of anserine and carnosine. Yakugaku Zasshi (in Japanese), 96, 1481-1486.

3) Margolis, F. L. (1974): Carnosine in the primary olfactory pathway. Science, N. Y., 184, 909-911.

4) NG, R. H., Marshall, F. D., Henn, F. A., and Sellström, §̊. (1977): Metabolism of carnosine and homocarnosine in subcellular fractions and neuronal and glial cell-enriched fractions of rabbit brain. J. Neurochem., 28, 449-452.

5) Hama, T., Tamaki, N., Irzumi, H., and Kita, M. (1970): Observation on the changes of $\beta$-alanine, anserine and carnosine contents in liver and gastrocnemius of growing rat. Eiyo To Shokuryo (J. Jpn. Soc. Food Nutr.), 23, 389-393.

6) Tamaki, N., Tsunemori, F., Wakabayashi, M., and Hama, T. (1977): Effect of histidine-free and excess diets on anserine and carnosine contents in rat gastrocnemius muscle. J. Nutr. Sci.Vitaminol., 23, 331-340.

7) Tamaki, N., and Hama, T. (1976): Effects of thyroid hormone and dietary protein levels on the contents of anserine and carnosine in gastrocnemius muscle of rats. Eiyo To Shokuryo (J. Jpn. Soc. Food Nutr.), 29, 317--324.

8) Fisher, H., Konlande, J., and Strumeyer, D. (1975): Levels of histidine and histidine derivatives in breast muscle of protein depleted and repleted adult cockerels. Nutr. Metab., 18, 120-126.

9) Tamaki, N., Tsunemori, F., Wakabayashi, M., and Hama, T. (1977): Effect of vitamin $B_{1}, B_{2}, B_{6}$ or pantothenic acid deficient diet on the contents of anserine and carnosine in skeletal muscle of rats. Vitamins (in Japanese), 51, 395-399.

10) Tamaki, N., Nakamura, M., Harada, M., Kimura, K., Kawano, H., and Hama, T. (1977): Anserine and carnosine contents of muscular tissue of rat and rabbit. J. Nutr. Sci. Vitaminol., 23, 319-329. 
11) Winnick, R. E., and Winnick, T. (1959): Carnosine-anserine synthetase of muscle. I. Preparation and properties of a soluble enzyme from chick muscle. Biochim. Biophys. Acta, 31, 47-55.

12) Kalyanker, G. D., and Meister, A. (1959): Enzymatic synthesis of carnosine from $\beta$-alanyl adenylate and histidine. J. Am. Chem. Soc., 81, 1515--1516.

13) Hama, T., Tamaki, N., Iizumi, H., and Miyamoto, F. (1970): Effect upon the contents of $\beta$-alanine, anserine and carnosine in several organs of rat by the administration of 6 -azauracil, $\beta$-alanine or carnosine. Eiyo To Shokuryo (J. Jpn. Soc. Food Nutr.), 23, 175-179.

14) Leveille, G. A., Shapiro, R., and Fisher, H. (1960): Amino acid requirements for maintenance in the adult rooster. IV. The requirements for methionine, cystine, phenylalanine, tyrosine and tryptophan; The adequacy of the determined requirements. J. Nutr. 72, 8-15.

15) Chung-Hwang, E., Khurana, H., and Fisher, H. (1976): The effect of dietary histidine level on the carnosine concentration of rat olfactory bulbs. J. Neurochem., 26, 1087-1901.

16) Winnick, T., and Winnick, R. E. (1959): Pathways and the physiological site of anserine formation. Nature, 183, 1466-1468.

17) Aonuma, S., Hama, T., Tamaki, N., and Okumura, H. (1969): Orotate as a $\beta$-alanine donor for anserine and carnosine biosynthesis, and effects of actinomycin D and azauracil on their pathway. $J$. Biochem., 66, 123-132.

18) Reitman, S., and Frankel, S. (1956): A colorimetric method for the determination of serum glutamic oxalacetic and glutamic pyruvic transaminases. Am. J. Clin. Pathol., 28, 56-63.

19) Roth, J. S., and Allison, J. B. (1949): Effect of feeding excess glycine, L-arginine, and DL-methionine to rats on a casein diet. Proc. Soc. Exp. Biol. Med., 70, 327-330.

20) Deshrande, P. P., Harper, A. E., and Elvehjem, C. A. (1958): Amino acid imbalance on low fibrin diets. J. Biol. Chem., 230, 327-333.

21) Mcmanus, I. R. (1962): Enzymatic synthesis of anserine in skeletal muscle by N-methylation of carnosine. J. Biol. Chem., 237, 1207-1211.

22) Kalyanker, G. D., and Meister, A. (1959): Enzymatic synthesis of carnosine and related $\beta$-alanyl and $\gamma$-aminobutyryl peptides. J. Biol. Chem., 234, 3210-3218.

23) Aonuma, S., Hama, T., and TAmaki, N. (1970): Interconversion of the tritium labeled anserine and carnosine in rat liver and muscle. J. Biochem., 68, 581-583.

24) Datta, S. P., and Harris, H. (1951): Dietary origin of urinary methylhistidine. Nature, 168, 296--297. 